\title{
Twin pregnancy after kidney transplant - the insight of the prenatal and postnatal problems based on a case report
}

\author{
Marzena Michalak-Kloc ${ }^{1}$, Magdalena Kłosowska-Kwapisz², Ewa Rojas Perez', Kornelia Walczak², \\ Agata Kuszerska², Witold Malinowski ${ }^{3}$ \\ ${ }^{1}$ Neonatology Department with Neonatology Intensive Care Unit, University Hospital in Zielona Gora, Poland \\ ${ }^{2}$ Department of Obstetric and Gynecology, University Hospital in Zielona Gora, Poland \\ ${ }^{3}$ Department of Obstetric and Gynecology Nursing at the Faculty of Health Scienses, Pomeranian Medical University in \\ Szczecin, Poland
}

\section{ABSTRACT}

Twin pregnancy after a kidney transplant is rare and is known to be a high-risk pregnancy. Chances of getting pregnant after a kidney transplant are higher than for patients with renal chronic disease. The most common problems which can occur are: severe hypertension, preeclampsia, abruption of the placenta and fetal growth restriction. We present a case of twin pregnancy after a kidney transplant, on three immunosuppressant medications, complicated by arrhythmia treated by cardioversion, severe fetal growth restriction in twin 2 , and preeclampsia. The pregnancy was ended at nearly 28 weeks of gestation due to abruption of the placenta in the normally growing twin. The birth weight was as follows: in twin 1-1200 g and in twin 2-620 g. We present problems during the postnatal period and outcomes at 12 months of life.

KEY WORDS:

twin pregnancy, kidney transplant, immunosuppressant therapy.

\section{INTRODUCTION}

Data has shown that the pregnancy rate is higher after a kidney transplant (KT) and the miscarriage rate is lower than in the general population. However, the risk of adverse pregnancy outcomes such as preeclampsia, cesarean section and preterm delivery are much higher in the KT group than in the general population $[1,2]$. The most important determinant of adverse pregnancy outcomes is kidney function impairment not the fact of having KT [3]. The rate of multiple pregnancies in patients with chronic kidney disease is around $6 \%$. However, these pregnancies were associated with higher risk of adverse outcomes. Apart from preterm delivery, higher frequencies of small for ges- tational age (SGA), perinatal and neonatal mortality were also observed [4].

\section{CASE REPORT}

A 35-year-old patient three years after a kidney transplant due to glomerulonephritis on immunosuppressant therapy, conceived spontaneously a dichorionic diamniotic twin pregnancy (DCDA). A previous pregnancy (2012) was complicated by chronic kidney disease (glomerulonephritis) and ended by c-section in 27 weeks of pregnancy because of HELLP syndrome. The neonate died a few days after delivery. In the current pregnancy, the patient was admitted to the hospital (Tertiary Center) due to acute atrial fibrillation episode in 21 weeks of

\section{ADDRESS FOR CORRESPONDENCE:}

Ewa Rojas Perez, Neonatology Department with Neonatology Intensive Care Unit, University Hospital in Zielona Góra, Poland, e-mail: ewarojas@wp.pl 
TABLE 1. Summary of postnatal period in both twins

\begin{tabular}{|c|c|c|}
\hline Parameter & Twin 1 (normal growth) & Twin 2 (intrauterine growth restricted) \\
\hline Birth weight & $1200 \mathrm{~g}$ & $620 \mathrm{~g}$ \\
\hline Apgar score & $6-9-9-9$ & $4-6-7-7$ \\
\hline NICU & Yes & Yes \\
\hline Surfactant & Yes & Yes \\
\hline SIMV & From $2^{\text {nd }}$ day of life & From $1^{\text {st }}$ day of life \\
\hline Oscillatory ventilation & No & From $10^{\text {th }}$ day \\
\hline NAVA mode & No & Till $49^{\text {th }}$ day of life \\
\hline Non-invasive ventilatory support & From $7^{\text {th }}$ day of life till $25^{\text {th }}$ day & From $77^{\text {th }}$ day of life till $92^{\text {nd }}$ day \\
\hline PPHN & No & Yes \\
\hline Nitric oxide treatment & No & Yes (from $34^{\text {th }}$ till $49^{\text {th }}$ day of life) \\
\hline Catecholamine supply & No & Yes \\
\hline Passive oxygen therapy & From $25^{\text {th }}$ day of life till $43^{\text {rd }}$ day & From $92^{\text {nd }}$ day of life till $133^{\text {rd }}$ day \\
\hline Blood transfusion & Yes & Yes \\
\hline Parenteral nutrition & Till $16^{\text {th }}$ day of life & Till $19^{\text {th }}$ day of life \\
\hline BPD & Yes, mild & Yes, severe \\
\hline Retinopathy & Stage 1 & Stage $1 / 2$ \\
\hline Enteral feeding via the teat & From $53^{\text {rd }}$ day of life & From $132^{\text {rd }}$ day of life \\
\hline IVH & Stage 1 & None \\
\hline Stay in hospital & 65 days & 141 days \\
\hline Weight on discharge & $2920 \mathrm{~g}$ & $4880 \mathrm{~g}$ \\
\hline
\end{tabular}

NICU - neonatal intensive care unit; SIMV - synchronized intermittent mandatory ventilation; NAVA - neurally adjusted ventilatory assist; PPHN - persistent pulmonary hypertension of the newborn; BPD bronchopulmonary dysplasia; IVH - intraventricular hemorrhage

gestation. On admission, she had low blood pressure and complete arrhythmia. Blood results were within the normal range. She needed an electrical cardioversion and was put on heparin. On the ultrasound, DCDA twin pregnancy was confirmed, additionally, severe fetal growth restriction (FGR) with oligohydramnios of twin two was diagnosed. Furthermore, the pregnancy was complicated by hypertension and a change in hypertensive medication was needed due to poor control, her blood pressure was nicely controlled by labetalol. As an immunosuppressant therapy, she was receiving azathioprine, tacrolimus, and prednisone. In the subsequent ultrasounds during hospitalization deterioration of the condition of the growth restricted twin was observed. Due to poor medical and obstetrical history, the multidisciplinary team with the patient made the decision not to end the pregnancy due to the growth restricted fetus indication until 28 weeks, to improve chances of having at least one child. Further close monitoring of the mother and twin's condition during a stay in hospital was performed. At 27 weeks and 5 days, bleeding from the vagina was noted, on the ultrasound abruption of the placenta of the twin, which was growing normally, was confirmed and an emergency c-section was performed. The steroids for lung maturation and neuroprotection were given one day before the c-section. The weight of twin one was $1200 \mathrm{~g}$, with an Apgar score of 6-9-9-9 points and twin two (intrauterine growth restricted) $620 \mathrm{~g}$, Apgar score 4-6-7-7 points. Both twins were admitted to the Neonatal Intensive Care Unit. A summary of the postnatal period in both twins is provided in Table 1. A 12-month follow up revealed normal psychomotor development in twin one (normally growing twin) with weight and height on the $50^{\text {th }}$ centile. He caught up with his peers who were born appropriate for gestational age. In twin two (born below $3^{\text {rd }}$ centile) developmental delay was observed. His weight and height were below the $10^{\text {th }}$ centile. The developmental milestones of twin 2 are presented in Table 2.

\section{DISCUSSION}

The rate of successful pregnancies after kidney transplant is $61 \%$, however, $36 \%$ of these are preterm deliveries and $16 \%$ are extremely preterm (below 28 weeks) due to severe hypertension, preeclampsia, abruption of the placenta or severe fetal growth restriction. The occurrence of hypertension is around $65 \%$ and preeclampsia up to $38 \%[3,4]$. Severe fetal growth restriction is seen in $50 \%$ of cases. In the first year post kidney transplant, pregnancy should be avoided due to the time needed to stabilize the graft function and doses of immunosuppressant medications [5]. Usually after one year post-transplant proph- 
TABLE 2. Developmental milestones of twin 2 (intrauterine growth restricted)

\begin{tabular}{|c|c|c|c|c|}
\hline Age & Gross Motor & Fine Motor & Language & Social/Cognitive \\
\hline Newborn & $\begin{array}{l}\text { Muscle tone and reflexes } \\
\text { appropriate to the fetal age }\end{array}$ & $\begin{array}{l}\text { Grasping reflexes ap- } \\
\text { propriate to the fetal age }\end{array}$ & $\begin{array}{l}\text { No sucking and searching } \\
\text { reflex }\end{array}$ & \\
\hline 2 months of life & $\begin{array}{l}\text { On mechanical ventilation } \\
\text { with analgosedation - } \\
\text { neurological condition } \\
\text { cannot be assessed }\end{array}$ & $\begin{array}{l}\text { On mechanical ventilation } \\
\text { with analgosedation - } \\
\text { neurological condition } \\
\text { cannot be assessed }\end{array}$ & $\begin{array}{l}\text { On mechanical ventilation } \\
\text { with analgosedation - } \\
\text { neurological condition } \\
\text { cannot be assessed }\end{array}$ & \\
\hline 3 months of life & $\begin{array}{l}\text { Decreased tension in } \\
\text { the axial muscles with } \\
\text { excessive tension in } \\
\text { peripheral muscles. } \\
\text { Decreased tendon reflexes }\end{array}$ & $\begin{array}{c}\text { Limb tremors on touch and } \\
\text { dorsal flexion, especially on } \\
\text { the left side }\end{array}$ & Non-invasive ventilation & \\
\hline $\begin{array}{l}4 \text { months of life } \\
\text { (corrected age } \\
\text { of } 1 \text { month) }\end{array}$ & $\begin{array}{l}\text { Low spontaneous motor } \\
\text { activity. Decreased tension } \\
\text { in the axial muscles. } \\
\text { Symmetrical tendon } \\
\text { reflexes. Positive Moro } \\
\text { reflex and support reflex }\end{array}$ & $\begin{array}{l}\text { Foot clonus present. Grasp- } \\
\text { ing reflexes present }\end{array}$ & $\begin{array}{l}\text { Present sucking and seek- } \\
\text { ing reflex. Poor } \\
\text { sucking-swallowing- } \\
\text { breathing coordination. } \\
\text { Starts drinking some } \\
\text { portion through the teat }\end{array}$ & \\
\hline $\begin{array}{l}5 \text { months (corrected } \\
\text { age of } 2 \text { months) }\end{array}$ & $\begin{array}{l}\text { Low spontaneous motor } \\
\text { activity, more marked on } \\
\text { the right side. Poor } \\
\text { stabilization in } \\
\text { the head-torso axis. } \\
\text { Raise head when lying on } \\
\text { the stomach. No symmetry }\end{array}$ & $\begin{array}{l}\text { Holds the rattle. The ten- } \\
\text { dency to footshake persists, } \\
\text { but it is less marked }\end{array}$ & $\begin{array}{c}\text { Proper coordination } \\
\text { of sucking-swallowing- } \\
\text { breathing }\end{array}$ & $\begin{array}{l}\text { Smiles in response } \\
\text { of speech }\end{array}$ \\
\hline $\begin{array}{l}6 \text { months (corrected } \\
\text { age of } 3 \text { months) }\end{array}$ & $\begin{array}{l}\text { Raise head and chest when } \\
\text { lying on the stomach. } \\
\text { Cannot roll over }\end{array}$ & $\begin{array}{l}\text { Clonuses absent. Connects } \\
\text { hands in the midline, } \\
\text { stretches straight arms } \\
\text { towards a toy, reaches out, } \\
\text { grabs and holds }\end{array}$ & Babbles & $\begin{array}{c}\text { Calms down at the sound } \\
\text { of a voice or when it is } \\
\text { taken in arms. Expresses } \\
\text { emotions }\end{array}$ \\
\hline $\begin{array}{l}12 \text { months of life } \\
\text { (corrected age } \\
\text { of } 6 \text { months) }\end{array}$ & Rolling over. Sits steadily & $\begin{array}{c}\text { Grabs with fingers, shifts } \\
\text { the rattle from hand to } \\
\text { hand, shakes it }\end{array}$ & $\begin{array}{l}\text { Spells and makes sounds to } \\
\text { attract attention. Reacts to } \\
\text { the word "no" }\end{array}$ & $\begin{array}{l}\text { Demonstrates devotion } \\
\text { to the caregiver. Imitates } \\
\text { gestures e.g. bye-bye }\end{array}$ \\
\hline
\end{tabular}

ylaxis is finished and doses of immunosuppressive drugs are reduced. Azathiopryne is a drug of choice during pregnancy. Prednisone and prednisolone can also be used as are in $90 \%$ inactivated by placental enzymes. Cyclosporine and tacrolimus are also allowed to be used. Contraindicated are mycophenolate mofetil and cyclophosphamide [6]. Most of the pregnancies (82\%) that were conceived during treatment consist of two medications and only $9 \%$ on three medications. However, only $3 \%$ according to research, conceived on regime consists of azathiopryne, tacrolimus and prednisone [7]. This immunosuppressant regime was used for our patient when she conceived twins. A further issue which is very important is the influence of immunosuppressant therapy on the fetus and the newborn. Observational studies suggest that azathioprine is safe in pregnant women. However, there are rare reports of congenital malformations such as: hypospadias, polydactyly, atrial or ventricular septal defect. Notwithstanding, there is no clear pattern of congenital malformations $[5,8,9]$. Prednisone in high doses above $40 \mathrm{mg} / \mathrm{d}$, can cause fetal growth restriction and

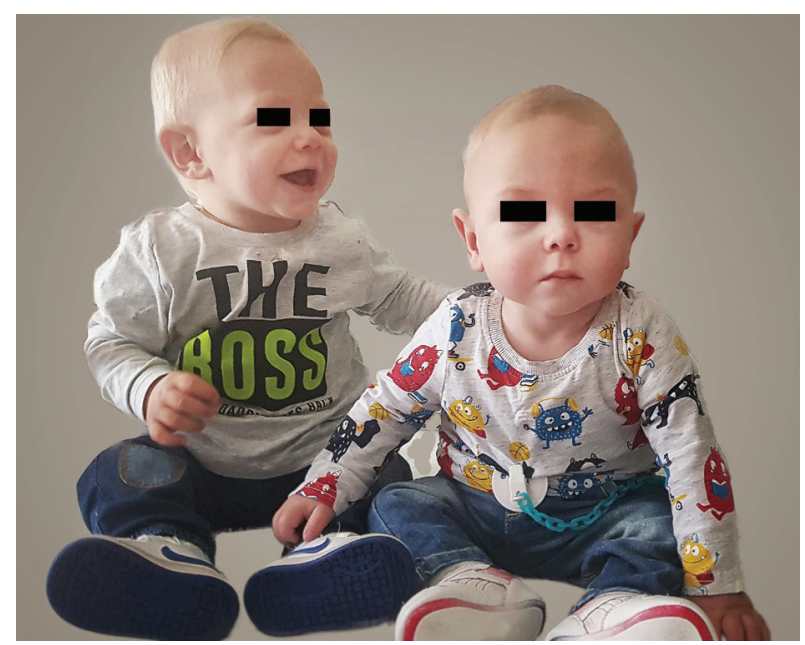

FIGURE 1. Twins at 12 months - on the right FGR twin, on the left normally growing twin

neurodevelopmental delay [10]. Some series show increased risk of cleft palate, but most of the data suggests no effects on the fetus $[5,11]$. In our case, the patient 
received low doses of prednisone, which makes it very unlikely that it was connected with FGR, especially that growth restriction was seen only in one twin. The third drug administered in our case was tacrolimus, which according to data does not cause fetal malformations and most authors reported favourable pregnancy outcomes [5, $6,12]$. However, there are consistent data that tacrolimus therapy can be connected with preterm delivery and low birth weight [13-15]. Furthermore, hypertensive medications such as labetalol ( $\beta$-blockers) can be a cause of low birth weight, but in the described case, labetalol was added to the therapy when severe FGR in twin 2 was already diagnosed. Furthermore, there are no data about the side effect of the immunosuppressant therapy on the outcome of the babies at 12 or 24 months. At 12 months, according to literature, $93.75 \%$ and at 24 months $95.2 \%$ of the babies had normal development. The mild neurological deviations (muscle tone disturbances in lower limbs and slightly reduced muscle tone in lower limbs) were noted at one year of age only in babies who were born very prematurely. Notwithstanding, the respective findings had improved at age two [16]. In our case, the FGR twin has some motor development delay, but it seems to be caused by the fact of severe growth restriction and severe prematurity rather than the therapy adopted, as the development of the twin's brother is normal (Fig. 1). Therefore, we can assume that the factor with the most influence on the outcomes is not the fact of having an organ transplant but prematurity and growth restriction, which are caused by the complexity of the medical condition. Additionally, based on this case report, we can identify how important cooperation and multidisciplinary teamwork is, as obstetrics and neonatology are not separate branches of medicine but are a continuity of each other.

\section{DISCLOSURE}

The authors declare no conflict of interest.

\section{REFERENCES}

1. Cabiddu G, Spotti D, Gernone G, et al. A best-practice position statement on pregnancy after kidney transplantation: focusing on the unsolved questions. The Kidney and Pregnancy Study Group of the Italian Society of Nephrology. J Nephrol 2018; 31: 665-681.

2. Deshpande NA, James NT, et al. Pregnancy outcomes in kidney transplant recipients: a systemic review and meta-analysis. Am J Transplant 2011; 11: 2388-2404.

3. Piccoli GB, Cabiddu G, Attini R, et al. Outcomes of pregnancies after kidney transplantation:Lessons learned from CHD. A comparison of transplanted, nontransplanted chronic kindey disease patients and low-risk pregnancies:A Multicenter Nationwide Analysis. Tronsplantation 2017; 101: 2536-2544

4. Piccoli GB, Arduino S, Attinin R, et al. Multiple Pregnancies in CKD patients: An explosive mix. Clin J Am Soc Nephrol 2013; 8: 41-50.
5. Chandra A, Midtvedt K, Asberg A, et al. Immunosuppresion and reproductive health after kidney transplantation. Transplantation 2019; 103: e325-e333.

6. Colla L, Diena D, Rossetti M, et al. Immunosuppression in pregnant women with renal disease: review of the latest evidence in the biologics era. J Nephrol 2018; 31: 361-383.

7. Bachmann F, Budde K, Gerland M, et al. Pregnancy following kidney transplantation - impact on mother and graft function and focus on childrens' longitudinal development. BMC Pregnancy Childbirth 2019; 19: 376.

8. de Boer NK, Jarbandhan SV, de Graaf P, et al. Azathioprine use during pregnancy: unexpected intrauterine exposure to metabolites. Am J Gastroenterol 2006; 101: 1390-1392.

9. Cleary BJ, Källẻn B. Early pregnancy azathioprine use and pregnancy outcomes. Birth Defects Res A Clin Mol Teratol 2009; 85: 647-654.

10. Park-Wyllie L, Mazzotta P, Pastuszek A, et al. Birth defects after maternal exposure to corticosteroids: prospective cohort study and meta-analysis of epidemiological studies. Teratology 2000; 62: 385392.

11. Carmichael SL, Shaw GM, Ma C, et al. National Birth Defects Prevention Study. Maternal corticosteroid use and orofacial clefts. Am J Obstet Gynecol 2007; 197: 585.e1-585.e7.

12. Kainz A, Harabacz I, Cowlrick IS, et al. Review of the course and outcome of 100 pregnancies in 84 women treated with tacrolimus. Transplantation 2000; 70: 1718-1721.

13. Jain AB, Reyes J, Marcos A, et al. Pregnancy after liver transplantation with tacrolimus immunosuppression: a single center's experience update at 13 years. Transplantation 2003; 76: 827-832.

14. Jain AB, Shapira R, Scantlebury VP, et al. Pregnancy after kidney and kidney-pancreas transplantation under tacrolimus: a single center's experience. Transplantation 2004; 77: 897-902.

15. Jabiry-Zieniewicz Z, Kamiński P, Pietrzak B, et al. Outcome of four high-risk pregnancies in female liver transplant recipients on tacrolimus immunosuppression. Transplant Proc 2006; 38: 255-257.

16. Shah S, Christianson AL, Verma $P$, et al. Racial disparities and factors associated with pregnancy in kidney transplant recipients in the United States. PLoS One 2019; 14: e0220916. 